\title{
The Financial Crisis of 2008 - 2009 and the Arab States Economies
}

\author{
Ahmad M. Mashal \\ Business Administration Program, Arab Open University \\ Amman, Jordan \\ E-mail: ah_mashal@hotmail.com
}

Received: October 30, 2011

Accepted: November 24, $2011 \quad$ Published: February 16, 2012

Doi:10.5539/ijbm.v7n4p96

URL: http://dx.doi.org/10.5539/ijbm.v7n4p96

\begin{abstract}
This paper will examine the impact of the global financial crisis on the Arab counties during the period (2008-2009). The paper has shown that increasing inter-connected world economic and financial matters means more effects on countries with high exposure to the rest of the world.

The study finds that the various economies of the Arab countries were impacted by the crisis. The impacts varied between the Arab countries according to the nature of their economies and the degree of openness and the association with the global economy. Some governments in the region have moved to reassure depositors that their money is safe in addition to the overall economic reforms carried out. The study classified Arab countries into three groups depending on their economies structure.

The effects of the crisis spread to the Arab economies through several local and external factors. The paper found out that the direct impact of the crisis was less dramatic in the financial sectors of some Arab countries due to the low level of interlink ages with the international system. One important lesson from the crisis is to prevent financial contagion from crippling their domestic banking and non-banking financial sectors in addition to the needed work to restore macroeconomic stability and sustainable growth and to work together to face the current and future economic and financial crisis.
\end{abstract}

Keywords: Global financial crisis, Arab countries, Crisis impact, Banking, Economies

\section{Introduction}

The world financial crisis and subsequent recession in the global economy have affected the Arab economies. As a result of the slowdown in economic activity and the decline in domestic and foreign investment, the economic growth of these countries declined. However, economic shocks in Arab countries is not new in contemporary economies, but the severity of the economic slowdown in some of Arab countries and its coincidence with the recession in the global economy has shown how closely connected are the economies of the Arab countries and global economic markets. The effects of the crisis spread to the Arab economies for several local and external factors. The opening of Gulf States to global financial markets and the dependence of many Arab countries on oil revenues to finance economic activity were the most influential factors for extending of the crisis directly to those economies. For the non-oil countries, such as Jordan, Tunisia, Syria, Lebanon, Egypt, Morocco and Mauritania, the contraction in external demand of their main trading partners, especially the European Union countries, in addition to the decline in financial flows to these countries from tourism and remittances from workers abroad and foreign direct investment were other key factors that extended crisis to these countries. The factors that contributed to reducing the negative effects of the global crisis on the Arab economies were the speed of taking the necessary measures to cope with external shocks, to avoid the slowdown in economic activity and addressing the risks that threaten systemic stability of the banking sector. It also shows that the overall economic reforms carried out by a number of non-oil Arab countries since the late eighties and the nineties of the last century, helped to contain the repercussions of the crisis, and ease their ability to manage the consequences of this crisis on the financial situations and balance of payments.

This paper seeks to assess the effects of the crisis on the economies of Arab countries. To achieve this we begin with a review of the roots of the global financial crisis and draw some lessons from them followed by a review of the main channels through which the crisis spread to Arab economies, with a comparative analysis of the effects of the crisis and the actions taken to manage the consequences of the crisis. The paper concludes with some lessons 
learned and the potential work needed to restore macroeconomic stability and sustainable growth in the Arab countries.

Oil prices have traditionally been more volatile than other commodity prices since World War II, as Daly and Fayyad (2011) stated. The dynamics of demand and supply for oil in the global economy coupled with the activities of oil producers themselves ensures that an understanding of the volatile nature of oil prices is amongst the most topical pursuits of researcher's.

The Global Financial Crisis beginning in (2008) was preceded by a year of less acute financial turmoil, which substantially reinforced the cyclical downturn in oil prices. On of Daly and Fayyad (2011) empirical findings suggest that the predictive power of oil for stock returns increased after a rise in oil prices and during the Global Financial Crisis periods.

Early empirical studies by Gisser and Goodwin (1986) and Hickman et al. (1987) confirmed an inverse relationship between oil prices and aggregate economic activity. Darby (1982), Burbidge and Harrison (1984), and Bruno and Sachs $(1982,1985)$ documented similar oil price-economy relationships in cross-country analysis.

Hamilton (1983) made a definitive contribution by extending the analysis to show that all but one of the post-World-War-II recessions was preceded by rising oil prices, which other business cycle variables did not predict. Jones and Leiby (1996) find that the estimated oil price elasticity of GNP in the early studies ranged from -0.02 to -0.08 , with the estimates consistently clustered around -0.05 .

Several explanations have advanced as to why an inverse relationship exists between oil price movements and aggregate economic activity. Of these explanations, the classic supply-side model shows how rising oil prices slow GDP growth and stimulates inflation, in Rasche and Tatom (1977 and 1981), Barro (1984) and Brown and Yucel (1999). More recent studies by Gronwald (2008), Cologni and Manera (2008), Kilian (2008), Lardic and Mignon (2006, 2008), and Lescaroux and Mignon (2008) have somewhat confirmed the earlier findings.

\section{Roots of the crisis}

Many economists attributed the financial crisis that erupted in the United States and worsened after the collapse of the residential mortgage market and then spreading to other parts of the world to several reasons. In the beginning, the U.S. banks since the nineties of the last century provided loans for lower-income borrowers or those with poor credit record, as justification for the dangerous lending was that housing prices have been rising rapidly in various parts of the United States. In addition, the political priorities in the united states helped in this matter, where the federal agencies like (Fannie Mac) and (Freddie Mac), as federal housing mortgages guaranteed by the U.S. government to support the mortgage market, were active in refinancing mortgages, which led, to a significant increase in bank's lending to mortgages. On the other hand, the process of converting mortgages into securities by investment companies and entities in the secondary market played a major role in the outbreak of the crisis. Where the securitization of mortgages in the form of securities have the highest rating by dividing them into segments of complex derivatives without a clear understanding of the level of risk incurred by these financial products, and then, foreign investors from different parts of the world invested in these securities. These financial innovations have remained away from the financial regulators of the capital market.

As housing prices dropped in the United States and the increase of payment delay by borrowers beside the deterioration of the credit rating of securities, market turmoil began in the money market first, then the Institutions and investment entities liquidated securities backed by assets, where commercial banks provided a guarantee or commitments to support them. Despite the collapse of the market prices of securities backed by assets, banks have continued providing loans to companies and investment entities in order to meet their obligations, even though the securities with banks were deposited in off-balance sheet framework to reduce the amount of money needed to meet the legal requirements of the banks. With the increasing difficulty of borrowing in the interbank market, banks face hard choices on the integration of the values of securities backed by assets in their balance sheets. And when a larger investment banks in the United States failed (Leman Brothers) to fulfill its obligations and announced its bankruptcy in September 2008, uncertainty and lack of confidence in major U.S. banks, were spreading. Then banks stopped financing through the interbank markets and started to store liquidity in their possession and tried to recover the funds by selling loans in the securities markets.

However, difficulties in the sale of these loans have forced banks to keep more loans on their books, and the resulting shortage of liquidity was unprecedented in the interbank markets, it quickly spread abroad. For example, Norton rock bank in UK could not sell existing mortgages on its books, leading it to request emergency funding from the bank of England. Also banks outside the United States have been exposed to bankruptcy, including in particular Banks of the small European countries such as Iceland, which failed to sell or securitize American 
mortgages in the books.

In addition to the above, branches of international banks located in emerging economies markets contributed to the spreading of liquidity shortages in the domestic markets of these countries. When the liquidity crisis broke out in the interbank markets of the developed countries, following (Lehman Brothers) bankruptcy announcement in sept.2008, a number of emerging countries economies experienced a liquidity squeeze, where some of international banks located in the local markets in eastern European states, decided to withdraw money deposited in their branches abroad and transfer them to headquarters in developed countries, in order to rebuild the bank capital bases. It should be noted here that the credit extended by branches of foreign banks located in the local markets in Eastern Europe, represented about 60 per cent of the total domestic credit on the majority of these countries. Given also the fact that the credit of foreign banks located in the countries of east Europe was the main source of funds coming from the headquarters of these banks and also deposited in foreign currency, the withdrawal of these banks' money caused banking system in a number of these countries to be destabilized. However, the experience of emerging economies of Latin America and South Asia in the effects of the crisis on them, did not show massive withdraw of capital by foreign banks located in the local markets during the crisis. According to the world bank reports, the reason for this was the fact that international banks located in emerging market economies in Latin America and South Asia were subject to many local restrictions, such as restrictions on the foreign exchange and compelling foreign banks to lend in local currency, and thus, it was difficult for the international banks located in the markets of these emerging economies to transfer the capital to their headquarters after the outbreak of the crisis.

One important lesson from the global financial crisis was that globalization of capital markets was offset by regulatory institution and supervisory systems for the banking and financial systems at the national level only, the global regulatory and supervisory to oversee the banking and financial system globally, was not available, so that whenever a major financial institution collapsed and caused large fluctuations in global financial markets, the regulator has taken the necessary measures at the global level to reduce the effects of systemic risk that may threaten the other major financial institutions located in the rest of the world.

It should be noted in this regard, that the authorities concerned in the group of twenty (G 20) since the beginning of the crisis moved quickly to remedy the tensions in global markets, and to take significant steps to address the consequences of the crisis on the banking system and the global financial world in an international context, and to allow joint adoption of national incentive frameworks consistent with each other, both in terms of providing the necessary liquidity to the banking system and the local financial institutions, or in relation to stimulus programs regarding financial growth and employment.

The group of twenty gave the bank of international settlements and international monetary fund and the financial stability board the responsibility for setting rules that promote the role of financial institutions in the activation of the global financial market, and to reduce the effect in the event of failure of these institutions and the spread of crisis to other financial institutions in the world.

\section{Comparative analysis of the effects of the crisis on Arab economies}

Arab economies passed through the global financial crisis and the consequent stagnation in the economies of most developed and developing countries during 2008 and 2009. The degrees of crisis effects have varied according to the nature of the Arab States economies and the degree of openness and its association with the global economy. For the purpose of analysis, Arab countries can be classified into three groups. The first group is the states of the Gulf Cooperation Council (GCC) (United Arab Emirates, Bahrain, Saudi Arabia, Oman, Qatar and Kuwait), characterized by open systems of financial and trade with high exposure to international financial markets, in addition to close association with the global financial system and global markets of commodities, particularly oil, gas and petrochemicals. This was the main channel for the extension of the global crisis to their economies. The second group (Algeria, Sudan, Libya and Yemen.), is regarded as their domestic capital markets are not directly linked to global markets, but their economies depend on oil revenues, so the global demand and oil prices affect the fiscal policy followed in these countries, that is, government expenditures rise with the rise of oil revenues and decrease with low income in most of these countries. The third group (Jordan, Tunisia, Syria, Lebanon, Egypt, Morocco and Mauritania) where banking and financial sector depends on the resources of local lending, and thus are not affected directly by fluctuations in global financial markets. However, the external shocks transmitted to these states economies through the close association with the commercial markets of developed countries and major trading partners in the EU and the U.S. In the commodity transactions, exports of these countries depend on the markets of developed countries primarily, as well as revenues of tourism, and remittances from workers abroad and foreign direct investment flows. 
And as a result of the fluctuations in the economic cycle and growth rates in developed countries, the economics of these countries groups would experience the risk of slowing growth, through the decline in their export sectors due to the high exposure to the developed markets and decline in financial flows to them through the fall of tourism revenues and remittances.

In doing a comparative analysis of the effects of the crisis on Arab economies of the three groups mentioned above, we can suggest that the extension of the crisis is due to the following factors: The first one concerns with the degree of financial exposure of the banking and financial sector in the local economies to the global financial markets, and the second factor was associated with commercial ties with major trading partners of the Arab states.

\subsection{First Group}

The financial factors relating to the opening on global financial markets formed the main channels for the crisis to hit the economies of the GCC. The GCC countries have witnessed in the years preceding the crisis a boom in the financial resources resulting from the huge increases in oil revenues and foreign capital inflows to finance large projects in a number of these countries, in addition to the expansion of bank extended credit to the private sector.

With the worsening of the financial crisis in developed countries and the shrinking of global demand after that, and the sharp decline of prices in international oil markets during the second half of the year 2008, as result, not only the financial surpluses of the GCC countries decreased but also the liquidity in the banking sector and the business sector in addition to the withdrawal of foreign financial flows, which hit the Gulf capital markets for speculative purposes, and thus investors' confidence was shaken in domestic economic conditions. It coincided with the lack of liquidity conditions in global markets. This led to a number of GCC countries to reduce their dependence on external funding for major projects. In addition to that many of the loans due to global financial institutions during the crisis were also in need of refinancing, which caused a number of companies, (public sector and private sector such as in Dubai debt crisis) to face the risk of re-schedule of outstanding debt and owe the increased cost of funding and the decrease of investments of real estate development projects and the purchase of real estate. This caused to postpone the implementation of several real estate development projects. According to international reports projects that have been postponed or frozen in the GCC countries at the end of 2009 were estimated at about $\$ 575$ billion, and that compared with the total projects that were under construction, was estimated at about $\$ 2.5$ trillion at the end of 2008 .

This has led to a decline in domestic demand for real estate, as property prices tumbled and impacted negatively on the value of the real estate assets that were included in the investment portfolios of the GCC banks. In light of these developments, uncertainty has increased and commercial banks followed the risk reduction strategies and the focus on supporting of their capital bases, prompting banks to a tightening in the terms of lending, which led to the decline in the growth of bank extended credit, followed by reduced growth in non-oil sectors and business sectors. In addition to the reduction in the supply of money (money and quasi-money) during the period 2006-2008. A growth rate of money supply reached around, $19 \%$, but the rate of the growth of money supply fell sharply after that.

\section{Insert Figure 1 - here}

The impact of the global crisis reflected on the fall of the world's stock markets indexes after that, and the impact was evident for the securities markets in countries of the Gulf Council. The loss to the market value of the GCC markets was about 41 per cent or the equivalent of $\$ 400$ billion during the period September to December 2008. As the indices of the GCC stock fluctuated in several markets, the Gulf stock markets have become infected by the global crisis very clearly. For example, when we compare the correlation coefficient of the stock markets indices for Gulf States combined before and during the crisis with the U.S. stock market (S \& P 500) the correlation coefficient trend change from inverse relationship before the crisis to positive one during the crisis.

\section{Insert Figure 2 - here}

In general, gulf banks have achieved relatively good financial results at the end of 2009, after they absorbed part of the losses arising from the crisis. And this may be contributed to the banking sector in all countries of the council to keep high rates of capital adequacy, prior to and during the crisis, and therefore the increase in non-performing loans as a proportion of total loans did not affect the financial results for the banking sector at the end of 2009 . Actually the sector achieved net profits, but came much less compared with its profits before the emergence of the financial crisis.

\section{Insert Table 1 - here}

The GCC banking sector also addressed itself to the systemic risks arising from the crisis. In addition, the official authorities in the GCC countries processed quick action to support the safety and stability of the banking and 
financial sector at local levels. Some of these actions came to support the liabilities of the banking and financial sectors, by pumping capital into the bank budgets as in each of the UAE and Qatar, where the value of paid-up capital reached 2 percent and 7.3 percent of GDP respectively. Also the monetary authorities in the GCC countries helped the banking sector by providing facilities and loans to local banks, in addition, the official authorities in Qatar supported local banks by buying portfolios of these banks, which were severely impaired in light of the decline in market indicators of the Doha securities market, where total purchase value reached of about 6 percent of Qatar GDP. The support of the "assets" of these banks was to improve the quality of their assets and provide the necessary liquidity to local banks, as well as to restore confidence in the stock market. At the same time each of the UAE, Qatar and Kuwait took decisions to guarantee deposits at local banks. This is in addition to the monetary authorities in the GCC countries to facilitate the use of monetary policy tools to boost liquidity in the banking sector through the reduction of reserve requirement ratios.

\section{Insert Table 2 - here}

In the context of stimulating economic activity, Saudi Arabia undertook the plan to stimulate and revive the national economy by adoption oil investments worth $\$ 400$ billion over the next five years. It is worth mentioning in this regard, that the amount of allocations is considered one of the highest allocations in the incentive programs applied by the group of twenty (G20). Other GCC countries also supported spending on infrastructure projects to stimulate aggregate demand, which in turn contributed to support the growth achieved in the non-oil sector in 2009, albeit lower than what the sector had achieved in previous years.

\subsection{Second Group}

The banking and financial sector in the countries of the second group (Algeria, Sudan, Libya and Yemen) were not directly affected by the repercussions of the global financial crisis as a result of being closed and not linked directly to the banking system in the financial world. Also the stock markets of Algeria and Sudan were not directly exposed to fluctuations in the market value due to the small volume and lack of the number of listed companies, in addition to the difficulty of entry for foreign investment. However, the economies of the group have been affected by the reduction of the demand for oil resulting from the recession in the global economy as a result of the global financial crisis. In addition, Algeria and Libya, the two members of OPEC reduced their production shares during 2008 and 2009, pursuant to the decision of OPEC to reduce production quotas. As a result of these factors, the average decline in the volume of oil exports of countries of the group reached 28 per cent in 2009, compared with the decline of 2 per cent in 2008.

\section{Insert Figure 3 - here}

On the other hand, the economies of the second group countries witnessed a remarkable growth in the activity of non-oil sectors, especially in Algeria and Libya. For Algeria, growth rates were good for the non-oil sectors in the light of the significant increase in the yield of agricultural grains, as well as continued high levels of public spending in infrastructure development under the national programmes to develop the infrastructure, as well as the accumulation of oil surplus before the emergence of the crisis. Libya, also witnessed a rapid growth of the non-oil sectors with the increase in public spending on infrastructure projects and the increased of foreign direct investment in Libya for the implementation of the infrastructure projects and construction. In Sudan and Yemen, the non-oil sectors recorded high growth rates like Algeria and Libya during the oil boom, with lower rate of growth, and in light of the availability of oil revenues before the emergence of the crisis. However, the decline in oil revenues following a decline in world oil prices impacted negatively on the non-oil economic activity. In Sudan, for example, the growth rate of economic activity for non-oil sectors declined from 8 per cent during the period (2006-2008) to about 3.8 per cent in 2009. This was due to a decrease in foreign investments, in addition to the interior factors and imposing procedures to reduce the demand for import in light of the sharp decline in foreign reserves resulting from the decline in oil prices.

\section{Insert Figure 4 - here}

\subsection{Third Group}

The limited exposure to international capital markets of the banking sector and the domestic financial instititutions in the third group (Jordan, Tunisia, Syria, Lebanon, Egypt, Morocco and Mauritania) has reduced the direct effects of the global financial crisis on these countries. However, the link of the group economies to economic activity and the demand in the developed countries, due to the focus of their exports and imports on the EU markets and the united states, as well as in the service and capital transactions, has had a negative impact on exports of the third group, and the flow of foreign direct investment, as a result of the shrinking demand in the developed countries. In general, the banking and the domestic financial sectors in this countries have avoided the negative effects 
witnessed by a number of emerging economies during the global financial crisis, due to the fact that the external transactions of domestic banks in the majority of the countries in this group were subject to restrictions on the movement of the capital flows, as local banks and financial institutions are committed to specific ceilings for investment abroad to reduce the exposure of their foreign assets to the high-risk investment as witnessed by the global financial markets during the crisis.

As for borrowing, the banking and financial sectors depended on the local resources. Even before the outbreak of the crisis, the securities markets of the third group were not affected by the fluctuations in the international stock markets, because the vast majority of investors in the local markets are individuals from the same countries with the presence of a limited foreign investment in a number of markets. However, the developments in global financial markets since the crisis of 2008 impacted negatively on the stock markets of several countries in the third group, due to the fluctuations in the international markets, including the European in particular. For example, a shift in the correlation coefficient of stock market indicators for the countries group with the French stock market (CAC 40) move from inverse relationship before the crisis to direct one during the crisis.

\section{Insert Figure 5 - here}

With regard to external financing, given the lack of global liquidity and the consequent rise in the cost of lending in the global markets, a number of countries in the third group were able to finance their budget depending on financial resources from the local market, as domestic liquidity recorded relatively high growth rate. The government borrowing from the domestic market coincided with a decline in the growth of bank loans to the private sector, which is due to the demand and supply factors resulting from the global crisis.

In this regard, the demand for bank credit declined in the light of shrinking external demand and lower global trade, in addition to the uncertainty caused by the global crisis led commercial banks to follow the precaution policy of not compromising the resources available to them in order to avoid tripping and increasing incidence of non-payment.

Insert Figure 6 - here

The effects of the consequences of the global crisis on bank lending to the private sector were obvious for Jordan and Egypt, which witnessed a decline in the growth of the bank loans to the private sector during 2008 and 2009.

In Jordan, the economy was affected by pressures on liquidity within banks following the monetary authorities' adoption of policy of supporting the value of the Jordanian Dinar against the dollar. Also the capital market was affected by the global crisis from the fourth quarter of 2008. In Egypt, the growth of bank credit to the private sector was weak before the crisis, in the light of the sector restructuring of the banking assets and reducing the proportion of non-performing loans. As a result of the decline in economic activity the growth of bank credit to the private sector, registered a negative rate at the end of 2009.

\section{Insert Figure 7 - here}

In light of the structural reforms in the banking sector, applied by countries in the third group preceding the consequences of the crisis, where banking sector in several countries in the group achieved a good result before the crisis by raising the risk -weighted capital adequacy ratio, and reduce the average ratio of non-performing loans to total loans. The banking sector in these countries cancelled many of the bad loans which were fully covered by provisions, which improved the efficiency and profitability of the banking sector in a number of these countries, where they managed to achieve relatively high returns on assets and on the equity of shareholders. Generally the performance of the banking sector in the countries of the group was not affected by the crisis during 2008 and 2009.

\section{Insert Table 3 - here}

However, the economic activity in the countries of the third group was affected by the decline in the external demand, where exports fall back and reduced remittances from workers abroad decreased and reduced the flow of foreign direct investment, at a time when the tourism sector has witnessed a slight improvement. The deteriorating conditions of the export sector have reflected on the pace of economic activity in the countries of the group by virtue of the connection of this sector with the rest of the production and service sectors, including banking sector, which obliged the authorities in the group countries to take swift action to facilitate the management of monetary policy and increase public spending through the economic stimulus program and stimulate growth and avoid recession and reduce the aggravation of unemployment.

\section{Insert Figure 8 - here}

In this regard, let us shed some light on the efforts that have been taken in a number of countries in this group. In 
the area of monetary policy, Jordan, Tunisia, Egypt and Morocco have reduced the interest rates, to urge the commercial banks to increase their lending to the private sector. For example, the monetary authorities in Egypt took decisions to reduce deposit rate for one night between banks six times during the period February to September 2009 bringing the cumulative total reductions to 325 basis points. Also the monetary authorities in Jordan reduced the interest rate, three times during the year 2009, by 50 basis points each time. Also the countries group reduced the compulsory reserve ratio and opened new facilities for lending and provided more liquidity to local banks, and guarantees for bank deposits.

\section{Insert Table 4 - here}

In the area of fiscal policy, both Tunisia and Egypt, have implemented a comprehensive package of measures to increase public spending and stimulate economic growth, as represented by the investment in infrastructure projects, education and support for the private sector, new jobs and export subsidies. Jordan, Syria and Morocco have increased public spending on investment in a number of development projects.

\section{Lessons learned}

The effects of the crisis on the performance of Arab economies varied among the countries groups. For example, the economic performance for the countries of groups I and II was affected more than the performance of the economies of the third group, as a result of the sharp decline in the yield of the oil sector following the decline in world prices for oil. It should be noted that growth in GDP of the non-oil sector was the main engine to achieve positive growth rates in GDP at constant prices in groups I and II.

\section{Insert Table 5 - here}

One of the lessons learned, was that the quick actions of the authorities in a number of Arab countries to manage the consequences of the global crisis on their economies by pursuing policies and procedures for fiscal and monetary response to the negative effects of the crisis may have succeeded in reducing the outcome of these effects on the Arab economies. Also authorities have, in general, succeeded to intervene to activate the various productive and service sectors in the economy, as well as provide assistance and space needed for policy options, which allow the use of policy instruments necessary to revive the national economy. For example, the buildup of financial surpluses resulting from increased oil revenues before the global financial crisis helped a number of Gulf Cooperation Council countries to pump liquidity to the domestic banking system. Also that the space required for policy options available to the authorities in several countries in the third group, in addition to the economic reforms applied early during the past years, led a number of countries in the third group to achieve macroeconomic stability, and transform the chronic deficit in the budget to a surplus in Morocco, increasing its foreign reserves to reach levels not seen in these economies before.

When the crisis spread to the economies of the countries that implemented economic reforms in the third group, some of them moved quickly to implement programs to stimulate economic policies based on expansionary fiscal and monetary policies to support economic activity and maintain local growth trends and economic recovery, without recourse to implement a program to correct the imbalances in the balance of payments and the necessary economic reforms to restore macroeconomic stability.

On the other hand, the consequences of the global crisis have impacted the pace of economic reforms in a number of countries that introduced economic reforms in previous periods, the result was to postpone the implementation of new reforms which were planned before the crisis, such as Egypt which postponed the introduction of reforms to the VAT system and the expansion of its tax base and rationalization of rates applied to increase the efficiency of the allocation of productive resources in the economy as well as to defer the tax on real estate and reduce support for some commodities. It remains the responsibility of these countries to choose the favorable conditions for the resumption of economic reforms carried out during the past years.

\subsection{First group actions}

The gulf cooperation council (GCC) countries have worked to reduce the consequences of the global economic and financial crisis through the intervention of the governments by pumping liquidity and facilitate the conduct of monetary policy and increasing public spending to stimulate the national economy. The support of government raised the capacity of banking and financial sector in the GCC countries and helped to contain the systemic risk resulting from the crisis. Also the non-oil sector maintained its growth, in spite of the weakness of the banks' lending to the private sector. The expectations show that the full recovery of the economies of the GCC countries from the consequences of the financial crisis and global economic might take some time before achieving sustainable growth rates in the light of the volatility in the global economy after the crisis. The consequences of the crisis have shown the growing risk of bank lending in some countries, during the years of economic boom resulting 
from high oil revenues, as well as heavy reliance on funding from abroad and the increasing exposure of the assets of many gulf banks on the real estate and securities, with recourse to the use of hot money and short-term deposited to finance projects and long-term loans. It also shows that the supervisory role of the banking and financial system in some states of the gulf council was unable to keep pace with rapid developments in the local banking and financial sectors due to the complexity of the connections with the banking and financial system globally.

On the other hand, the consequences of the global crisis showed the dangers of domination of the oil sector in the national economy and the dependence on oil revenues, which requires the intensification of reform efforts taken by the GCC countries during the past two decades to diversify the economy base and increase non-oil revenues and expand private sector participation in economic activity, and to maintain savings from the proceeds of oil revenue to implement expansionary fiscal policy during periods of economic recession and reduce the risk of dependence on the oil sector.

To keep the Cooperation Council Countries steps for the reform of the economic conditions arising from the crisis and restore the economy's ability to achieve sustainable growth, the banking sector was called upon to restore its role in financing economic development and to rebuild their capital bases and the disposal of the losses suffered by some banks took the risk of excessive lending. The GCC countries are also invited to intensify their efforts in the development of the regulatory and supervisory role on the banking systems to keep up with local rapid developments in the light of the complexity of the connection of the local systems with the global banking system.

In the economic policy side, there is a need for more coordination between monetary and fiscal policies in a number of Gulf countries and to use the tools of macroeconomic management that help to slow down the transmission of oil cycle to the economy in light of the limited autonomy of their monetary policy linkage (of gulf currencies) to the dollar. The establishment and development of debt markets may help to diversify the portfolios of investors away from the scope of the banks' traditional role in strengthening the financial depth of the markets.

In terms of diversifying the economy and the expansion of private sector participation in economic activity, the GCC countries are invited to enhance the competitiveness of their economies through the development of the regulatory bodies of financial markets and removing restrictions to the rentier practices that hinder competition and does not attract domestic investment and foreign direct generator of employment or supporting the strategy of diversification in the economies of GCC countries.

\subsection{Second group actions}

The countries of the second group, namely, Algeria, Libya, Sudan and Yemen, were affected by the drop down of the world oil prices and their oil revenues, resulting in a lower surplus in the budgets and the balance of current account for Algeria and Libya and the deterioration of the deficit for the Sudan and Yemen. The domestic banking sector in the countries of the group was not affected by the global financial crisis because it is not directly connected and exposed to the global financial markets.

The countries in this group were able to pursue an expansionary fiscal policy in the public spending on infrastructure projects, housing and social programs in addition to providing support for some commodities, to activate of the economic cycle and allow the private sector to play a wider role in economic activity, which helped to achieve relatively high growth rates before and during the crisis, But the countries of the second group remain vulnerable to fluctuations in the prices of oil and the risk of depletion of oil surpluses, which requires the continuation of the reforms aimed to achieve efficiency in fiscal policy on the part of public expenditure so as to allow to go along with the economic cycle up and down and maintain the sustainable financial situation without resorting to significant adjustments in components of spending each time oil revenues fall.

The non-oil economic activity in the countries of the second group needs structural reforms to improve its performance through simplifying the procedures of doing business to expand the contribution of the private sector to diversify the production base and the generate productive jobs, and attract foreign direct investment accompanied by transfer of knowledge and technology to generate an added value to the national economy.

With regard to strengthening the role of monetary policy to cope with external shocks in the future, the monetary authorities in the countries of the second group are invited to deepen the reform of the banking system by restructuring and liberalizing the public banks sector and to end the unfair competition between public specialized banks and commercial banks and to let them work subject to central bank regulations to maintain liquidity and lending conditions on a commercial basis, and to make them work under banking supervision similar to private banks, and urge them to build their managerial capacity and attract administrative skills to deepen the banking financial intermediation and the innovation in financial products for the mobilization of domestic savings to be ready for investment in the private sector and the development of the local capital market. 


\subsection{Third group actions}

The limited exposure of the banking sector and the domestic financial markets to the global financial markets have contributed to avoid direct exposure to the global financial crisis by the economies of the third group. However, the slack of the global demand led to a slowdown in the groups' exports and the decline of private sector investment with the accompanying decline in the demand for bank credit.

In spite of this, the performance of the banking sector in most countries in the group was not affected, due to the efforts made by these countries to reform and liberalize of the banking sector, as part of comprehensive economic reform programs which were done before the crisis. Also these countries have been able to restructure the local banking system, including increasing the rates of capital adequacy and reducing the proportion of non-performing loans to total loans while improving the quality of credit portfolios of banks. These reforms contributed to the resilience of the banking sector in facing the external shocks. The economies of these countries have achieved an estimated average growth rate of 4.5 per cent in 2009, compared with the average growth rates about 6 per cent during the period before the financial and economic crisis, which are well above what has been recorded by many countries of the emerging economies.

In the area of monetary policy, the monetary authorities in the countries of the third group made real efforts to reduce the effects of global crisis on economic activity through the use of policy instruments available to them. The result was a good return of this policy on the banking and financial sector with the decline in inflationary pressures in the economy. Tunisia, Egypt and Morocco worked to create good conditions to achieve price stability.

The global crisis demonstrated the need for the continuation of the monetary authorities in several countries in the group to deepen structural reforms for the banking sector, in reducing the proportion of non-performing loans and work on the application of Basel II Accord concerning the risk-weighted capital ratio, and increase transparency for investors and bank depositors about the risks that commercial banks may be exposed to, and strengthen the oversight role of the supervision authorities on local banking systems in order to avoid systemic risk.

It is also important to continue to pursue and deepen economic reform in the countries of the group to support the resilience of national economies in the face of the challenges created by the global crisis. In light of the decrease of exports due to shrinkage of external demand and decline in remittances from workers abroad, in addition to the deterioration of the balance of current account of the countries of the third group, they were obliged to develop and implement a package of measures to increase public spending and stimulate local economic activity, and thus the budget deficit and the financial performance indicators have deteriorated in the countries committed to achieve certain targets in the implementation of their economic reform programs. Despite the high proportion of the budget deficit to GDP for a number of countries group, the existing stock of debt as a proportion of GDP was not affected much. Some of the countries in the third group used the foreign reserves that had accumulated during the economic boom before the crisis, and others have been able within this group to rely on the liquidity available in the local commercial banks to finance the budget deficit with slight increase in return on new versions of the treasury bills.

Despite the expectations of the international financial institutions for the next improvement in global demand and growth, the continued volatility in global financial markets and uncertainty in the economies of developed countries may suggest increasing of adverse effects in the future. The continued reluctance of the private sector for investment and the weak growth of bank extended credit to the private sector may delay the solution of the problems. The governments of the group continued to pursue an expansionary fiscal policy to deal with the economic recession and to continue the proceedings to stimulate economic activity like giving tax incentives to some production and export activities. But to pursue expansionary fiscal actions may affect the financial situation of fiscal sustainability in the medium term, and it becomes necessary to return to work on achieving the targeted financial indicators before the crisis, to ensure macroeconomic stability. Therefore, there is a need to resume the process of structural reforms in the field of rational public expenditure, improve financial transparency and to further reforms in revenue, as increasing the level of income tax and the size of its contribution to total revenue on the one hand, and reducing administrative costs and removing distortions in the economic incentives, on the other hand.

\section{Conclusion}

It is obvious that the 2008 global financial crisis provides a good opportunity for the Arab countries to work together to face the consequences of the economic and financial crisis in a coordinated way and to initiate and develop alternative policies, as plans for macroeconomic stabilization, a new system of financial and banking regulation that should be built on two principles: the need to incorporate counter-cyclical mechanisms in order to correct for the boom-bust nature of financial markets, and effective regulation whereby the domain of the regulator is the domain of all countries markets. 
Finally, there is a necessity to go beyond the mere short-term management of the crisis and to implement an efficient regional policy response to enhance the stability of the Arab countries financial systems and to stimulate the economic growth.

\section{References}

Abu-Ismail, K., \& Pournik, M. (2009). The Impact of the Global Financial crisis on Arab States and Policy Reactions. UNDP Regional Center in Cairo, August.

Akyuz, Yilmaz. (2008). The global financial crisis and developing courtiers. Third world Network.

Ali AlKuwari. (2009). The third oil boom. Preliminary reading of its cases and magnitude: the setting of the Gulf cooperation Council (GCC). Contemporary Arab Affairs, 2(2), 304-318. http://dx.doi.org/10.1080/17550910902856952

Arab Monetary Fund.

Arab Petrolrum Research Center. (2009). Arab Oil \& Gas Bulletin, Vol.xxxviii-No900, 16 March.

Barry Eichengreen. (2010). Lessons of the crisis for emerging markets. International Economics and Economic Policy, 7(1), 49-62.

Behrendt, C., Haq, T., \& Kamel, N. (2009). The Impact of the Finanical and Economic Crisis on Arab States: Considerations On employment and Social Protection Policy Responses. Beirut: ILO Regional Office for Arab States.

Cali, M., \& Dell Eroba, S. (2009). The Global Financial Crisis and Rami Hances: What past evidence Suggests. Working Paper303 (London, UK).

Daly, K., \& Fayyad, A. (2011). World Oil Prides \& Stock Market Return! The Case of GCC Countries, UK \& USA. Emerging Markets Review, 12(1), 61-78.

Diverse Newspapers and Media

European Commission. (2009, June). Impact of the Global crisis on Neighboring Countries of the EU, Occasional Papers 48.

Foxley, A. (2009). Recovery: The Global Financial Crisis and Middle-Income Countries. Carnegie Endowment for International Peace.

Ghosh, Jayati., \& C. P. Chandrasekhar, eds. (2008). Adecade after Financial crisis and recovery in East Asia, New Delhi. Tulika: the Global Financial Crisis, Development countries and policy Responses (March 2009)

Gronwald, M. (2008). Large oil shocks and the US economy: Infrequent incidents with large effects. Energy Journal, 29, 151-71. http://dx.doi.org/10.5547/ISSN0195-6574-EJ-Vol29-No1-7

Husain, A., \& Tazhibyeva K. Economic Cycles in Oil-Exporting Countries. IMF Working paper (WP/08/253), November.

IMF. (2009). Regional Economic Outlook: Middle East and central Asia. IMF, Washington, DC.

IMF. (2010, March). Impact of the Global Financial Crisis on the Gulf Cooperation Council and Challenges Ahead.

Kilian, L. (2008). Exogenous Oil Supply Shocks: How Big Are They and How Much Do They Matter for the US Economy. Review of Economics and Statistics, 90, 216-40. http://dx.doi.org/10.1162/rest.90.2.216

Lardic, S., \& Mignon, V. (2006). The impact of oil prices on GDP in European countries: An empirical investigation based on asymmetric co-integration. Energy Policy, 34 (18), 3910-3915. http://dx.doi.org/10.1016/j.enpol.2005.09.019

Lardic, S., \& Mignon, V. (2008). Oil prices and economic activity: An asymmetric co-integration approach. Energy Economics, 30 (3), 847-855. http://dx.doi.org/10.1016/j.eneco.2006.10.010

Lescaroux, F., \& Mignon. V. (2008). On the influence of oil prices on economic activity and other macroeconomic and financial variables. OPEC Energy Review, 32 (4), 343-380. http://dx.doi.org/10.1111/j.1753-0237.2009.00157.x

Mauro F. Guilen. (2008). The Global Economic \& Financial crisis and Developing countries. Overseas Development Institute (ODI), UK, (October, 2008).

MEED, Dec. 2009. 
Middle East and North Africa Regional overview. September 2009.

Ms. Shamshad Akhtar. (2009). MENA Economic Developments and Prospects. [Online] Available: http://siteresources.worldbank.org/INTMENA/Resources/FinalDocumentofEDPPressPresentationSAOct32009.p df (October3, 2009)

United Nations. (2009). World Economic Situation and Prospects 2009, New York.

Table 1. Performance indicators and safety of the banking sector in the first group

\begin{tabular}{|c|c|c|c|c|c|c|c|c|c|c|}
\hline & \multicolumn{2}{|c|}{$\begin{array}{l}\text { Capital Adequacy } \\
\text { Ratio (\%) }\end{array}$} & \multicolumn{2}{|c|}{$\begin{array}{l}\text { The proportion of } \\
\text { non-performing loans } \\
\text { to total Loans (\%) }\end{array}$} & \multicolumn{2}{|c|}{$\begin{array}{l}\text { The proportion of } \\
\text { allocations to Total non- } \\
\text { performing loans }(\%)\end{array}$} & \multicolumn{2}{|c|}{$\begin{array}{l}\text { Rate of return on } \\
\text { Assets } \%\end{array}$} & \multicolumn{2}{|c|}{$\begin{array}{c}\text { Rate of return on } \\
\text { shareholders' equity (\%) }\end{array}$} \\
\hline & 2007 & 2009 & 2007 & 2009 & 2007 & 2009 & 2007 & 2009 & 2007 & 2009 \\
\hline U.A.E & 14.0 & 18.6 & 2.9 & 4.6 & 100.0 & 79.0 & 2.0 & 1.5 & 22.0 & 12.1 \\
\hline Bahrain & 21.0 & 19.6 & 2.3 & 3.9 & 74.0 & - & 1.2 & 1.2 & 18.4 & 10.6 \\
\hline KSA & 20.6 & 16.5 & 2.1 & 3.3 & 142.9 & 89.8 & 1.9 & 1.9 & 22.3 & 13.7 \\
\hline Oman & 15.9 & 15.5 & 3.2 & 2.8 & 111.8 & 113.8 & 202 & 2.2 & 14.3 & 14.2 \\
\hline Qatar & 13.5 & 16.1 & 1.5 & 1.7 & 90.7 & 84.5 & 203 & 2.3 & 25.5 & 19.9 \\
\hline Kuwait & 18.5 & 18.9 & 3.2 & 9.7 & 77.0 & 51.1 & 0.8 & 0.8 & 25.0 & 6.5 \\
\hline
\end{tabular}

Source: Survey Unified Arab Economic Report for 2010. Indicators for each of the UAE, Bahrain, Oman and indicators of rates of non-performing loans and provisions for Kuwait taken from the IMF study: IMF "Impact of the Global Crisis on the Gulf Cooperation Council and Challenges Ahead", (March 2010).

Table 2. Actions taken to support financial stability and reduce the effects of global crisis on the banking sector in the countries of the first group

\begin{tabular}{|c|c|c|c|c|c|c|c|}
\hline & $\begin{array}{c}\text { Guarantee } \\
\text { of Banking } \\
\text { Deposits }\end{array}$ & $\begin{array}{c}\text { Provided } \\
\text { liquidity to the } \\
\text { banking sector }\end{array}$ & $\begin{array}{c}\text { Government } \\
\text { long term } \\
\text { deposit }\end{array}$ & $\begin{array}{c}\text { pumping } \\
\text { Capital to } \\
\text { Banks }\end{array}$ & $\begin{array}{c}\text { purchase } \\
\text { Banks } \\
\text { portfolios }\end{array}$ & $\begin{array}{c}\text { Buy banks shares } \\
\text { Traded in the } \\
\text { market }\end{array}$ & $\begin{array}{c}\text { Easing the } \\
\text { monetary } \\
\text { policy }\end{array}$ \\
\hline U.A.E & $\checkmark$ & $\checkmark$ & $\checkmark$ & $\checkmark$ & & & $\checkmark$ \\
KSAR & $\checkmark$ & $\checkmark$ & $\checkmark$ & $\checkmark$ & $\checkmark$ & & $\checkmark$ \\
Oman & $\checkmark$ & $\checkmark$ & $\checkmark$ & $\checkmark$ & $\checkmark$ & $\checkmark$ \\
Kutar & $\checkmark$ & $\checkmark$ & $\checkmark$ & $\checkmark$ & $\checkmark$ & $\checkmark$ & $\checkmark$ \\
\hline
\end{tabular}

Source: National sources 
Table 3. Banking sector indicators in the countries of the third group

\begin{tabular}{|c|c|c|c|c|c|c|c|c|c|c|}
\hline & \multicolumn{2}{|c|}{$\begin{array}{c}\text { Capital Adequacy } \\
\text { Ratio }(\%)\end{array}$} & \multicolumn{2}{|c|}{$\begin{array}{l}\text { The proportion of } \\
\text { non-performing loans } \\
\text { to total Loans }(\%)\end{array}$} & \multicolumn{2}{|c|}{$\begin{array}{l}\text { The proportion of } \\
\text { allocations to Total non- } \\
\text { performing loans }(\%)\end{array}$} & \multicolumn{2}{|c|}{$\begin{array}{l}\text { Rate of return on } \\
\text { Assets } \%\end{array}$} & \multicolumn{2}{|c|}{$\begin{array}{c}\text { Rate of return on } \\
\text { shareholders' equity } \\
(\%)\end{array}$} \\
\hline & 2007 & 2009 & 2007 & 2009 & 2007 & 2009 & 2007 & 2009 & 2007 & 2009 \\
\hline Jordan & 20.8 & 18.3 & 4.1 & 4.2 & 67.8 & 63.3 & 1.6 & 1.4 & 14.0 & 11.5 \\
\hline Tunisia & 9.8 & 11.2 & 17.7 & 13.3 & 53.4 & 58.2 & 0.8 & 1.1 & 10.5 & 13.3 \\
\hline Syria & 16.4 & 19.0 & 5.3 & 5.1 & 23.7 & 17.9 & 2.4 & 1.1 & 23.9 & 20.0 \\
\hline Lebanon & 12.5 & 12.4 & 10.1 & 6.0 & 56.6 & 64.4 & 1.02 & 1.05 & 12.1 & 14.4 \\
\hline Egypt & 14.3 & 14.8 & 14.8 & 14.7 & 92.1 & 94.5 & 0.8 & 0.8 & 13.3 & 14.5 \\
\hline Morocco & 10.6 & 11.7 & 6.0 & 5.5 & 75.3 & 77.6 & 1.3 & 1.3 & 16.7 & 17.0 \\
\hline Mauritania & 10.0 & 10.0 & 35.1 & 27.0 & 61.5 & 85.0 & 4.0 & 4.0 & 10.2 & 16.0 \\
\hline
\end{tabular}

Source: Survey Unified Arab Economic report for 2010, and the international monetary fund article four reports

Table 4. The most important measures taken to address the financial crisis and global recession in the countries of the third group

\begin{tabular}{|c|c|c|c|c|c|c|}
\hline & \multicolumn{3}{|c|}{$\begin{array}{c}\text { The field of monetary policy and financial } \\
\text { land banking stability }\end{array}$} & \multicolumn{3}{c|}{ The field of public finance } \\
\hline & $\begin{array}{c}\text { Reduced interest } \\
\text { prime rates } \\
\text { (Monetary policy) }\end{array}$ & $\begin{array}{c}\text { Provision } \\
\text { of } \\
\text { Liquidity }\end{array}$ & $\begin{array}{c}\text { The reduction } \\
\text { of the } \\
\text { compulsory } \\
\text { reserves rates }\end{array}$ & $\begin{array}{c}\text { Insuring } \\
\text { Banks } \\
\text { deposits }\end{array}$ & $\begin{array}{c}\text { Implementation of a } \\
\text { package of } \\
\text { comprehensive measures } \\
\text { to stimulate economic } \\
\text { growth }\end{array}$ & $\begin{array}{c}\text { Implementatio } \\
\text { n of limited } \\
\text { Expansionary } \\
\text { fiscal } \\
\text { policies }\end{array}$ \\
\hline Jordan & $\checkmark$ & $\checkmark$ & $\checkmark$ & $\checkmark$ & $\checkmark$ & $\checkmark$ \\
Synisia & $\checkmark$ & $\checkmark$ & $\checkmark$ & $\checkmark$ & $\checkmark$ & $\checkmark$ \\
Lebanon & $\checkmark$ & $\checkmark$ & $\checkmark$ & $\checkmark$ & $\checkmark$ & $\checkmark$ \\
Morocco & $\checkmark$ & $\checkmark$ & $\checkmark$ & $\checkmark$ & & $\checkmark$ \\
Mauritania & $\checkmark$ & $\checkmark$ & & & $\checkmark$ \\
\hline
\end{tabular}

Source: National sources 
Table 5. Average rates of GDP growth for groups of Arab States at constant prices for the base year $2005=100$

\begin{tabular}{|c|c|c|c|c|c|c|c|c|c|}
\hline Groups of Arab States & \multicolumn{2}{|c|}{$\begin{array}{c}\text { Growth rates of the oil sector } \\
\text { for the period }\end{array}$} & \multicolumn{2}{|c|}{$\begin{array}{c}\text { Growth rates of non-oil } \\
\text { sector for the period }\end{array}$} & \multicolumn{3}{|c|}{$\begin{array}{c}\text { Growth rates of GDP for } \\
\text { the period }\end{array}$} \\
\hline & $2002-2005$ & $2006-2008$ & 2009 & $2002-2005$ & $2.006-20.08$ & 2009 & $2002-2005$ & $2006-2008$ & 2009 \\
The first group & 4.8 & 5.1 & -4.0 & 6.9 & 5.6 & 3.3 & 5.9 & 5.3 & 0.1 \\
The second group & 6.1 & 1.1 & -4.5 & 4.3 & 6.1 & 7.9 & 5.2 & 3.6 & 2.8 \\
The third group & - & - & - & - & - & - & 5.4 & 6.0 & 4.5 \\
\hline Groups of Arab States & 5.2 & 4.3 & -4.3 & 6.1 & 5.7 & 4.2 & 5.5 & 5.0 & 1.8 \\
\hline
\end{tabular}

*Growth rates for the oil and non-oil sector for the first and second group only.

Source: Unified Arab Economics Report, and domestic and international sources.

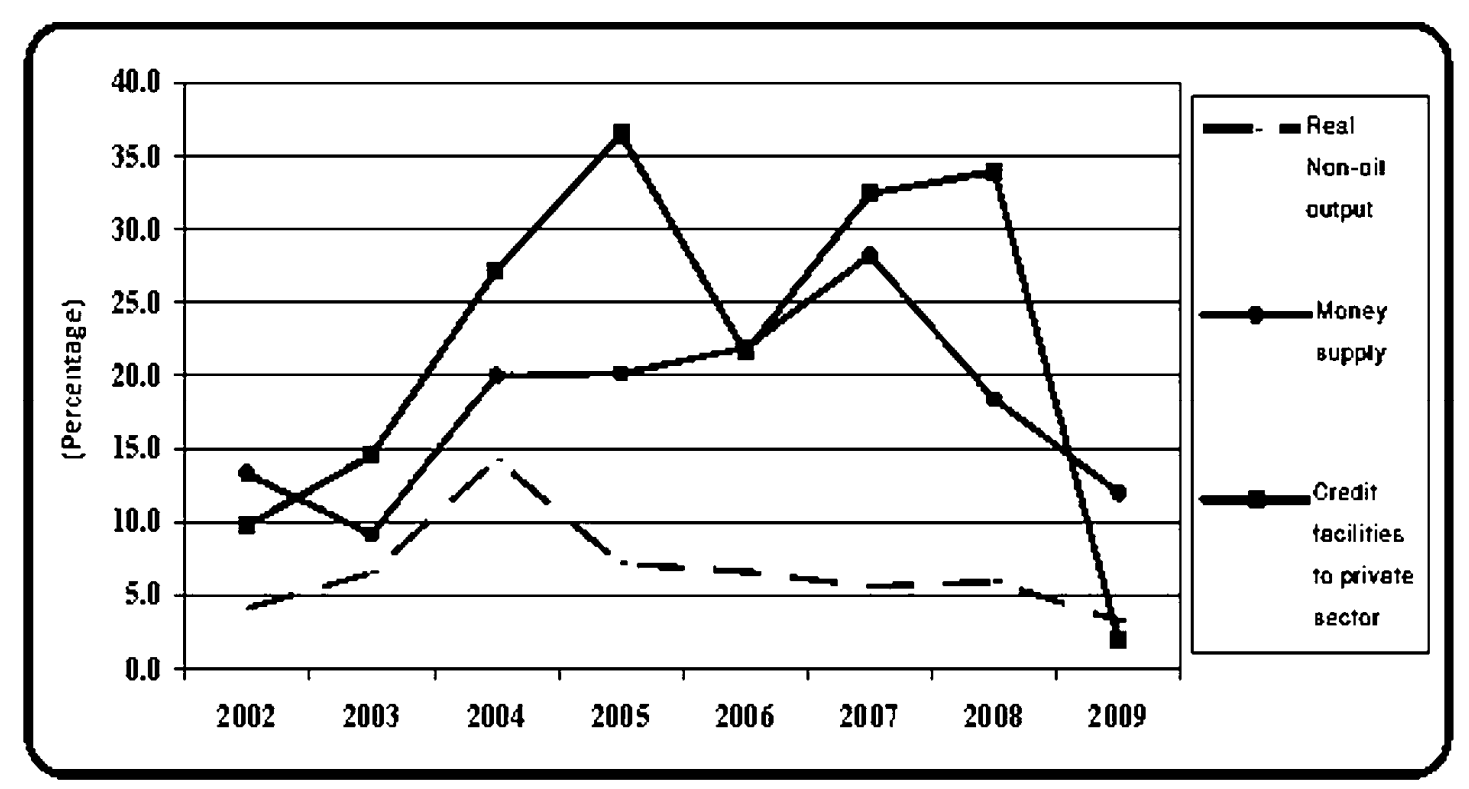

Figure 1. The growth trends of each of the banking extended credit to the private sector and the money supply and output of the local non-oil sector in the first group during the crisis (Annual percent change \%)

Source: The Arab monetary fund report for 2010 and previous years, the international monetary fund: International Financial Statistics (IFS) 


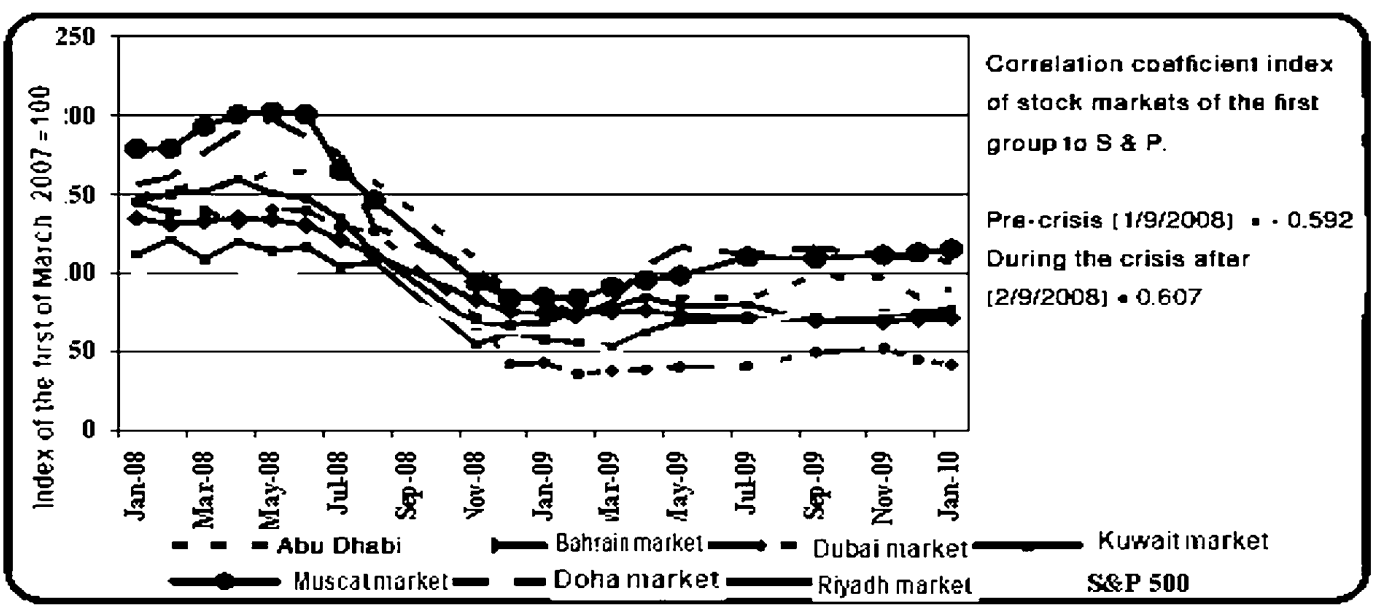

Figure 2. The direction of stock market indices for the countries of first group and the indicator of S \&p500 Source: Arab Monetary Fund - a database of Arab stock markets

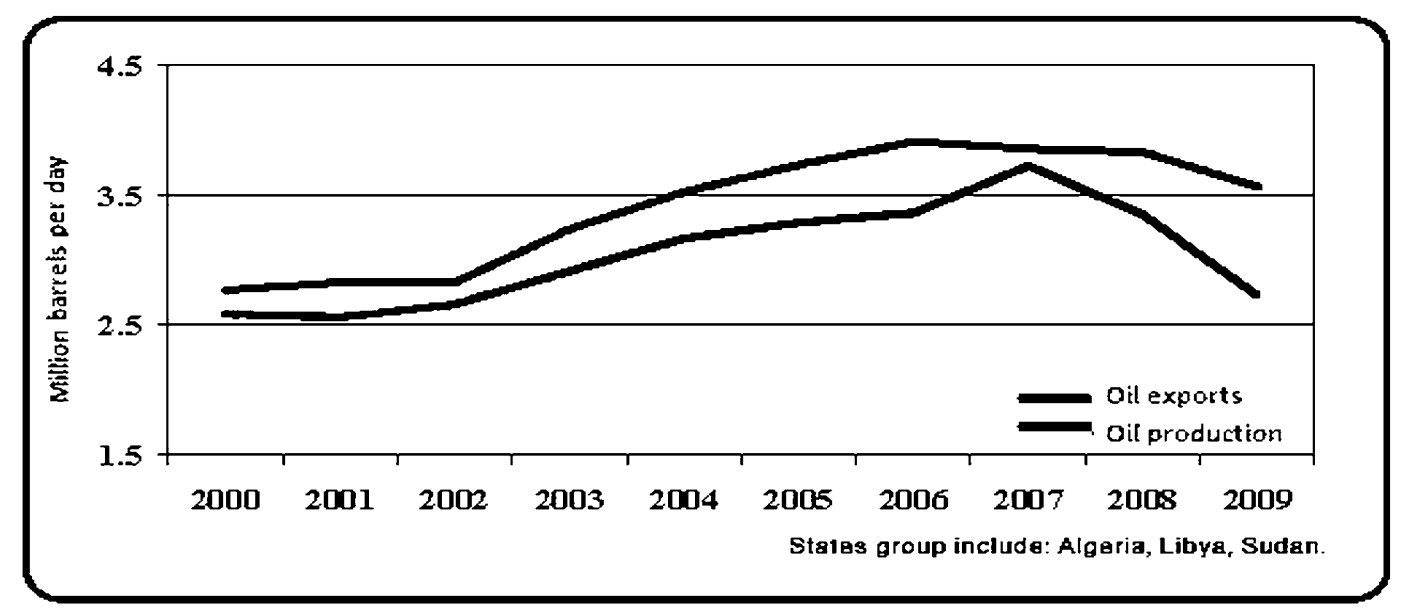

Figure 3. Production and exports of oil for the second group (2000-2009)

Source: OPEC Annual Statistical Report

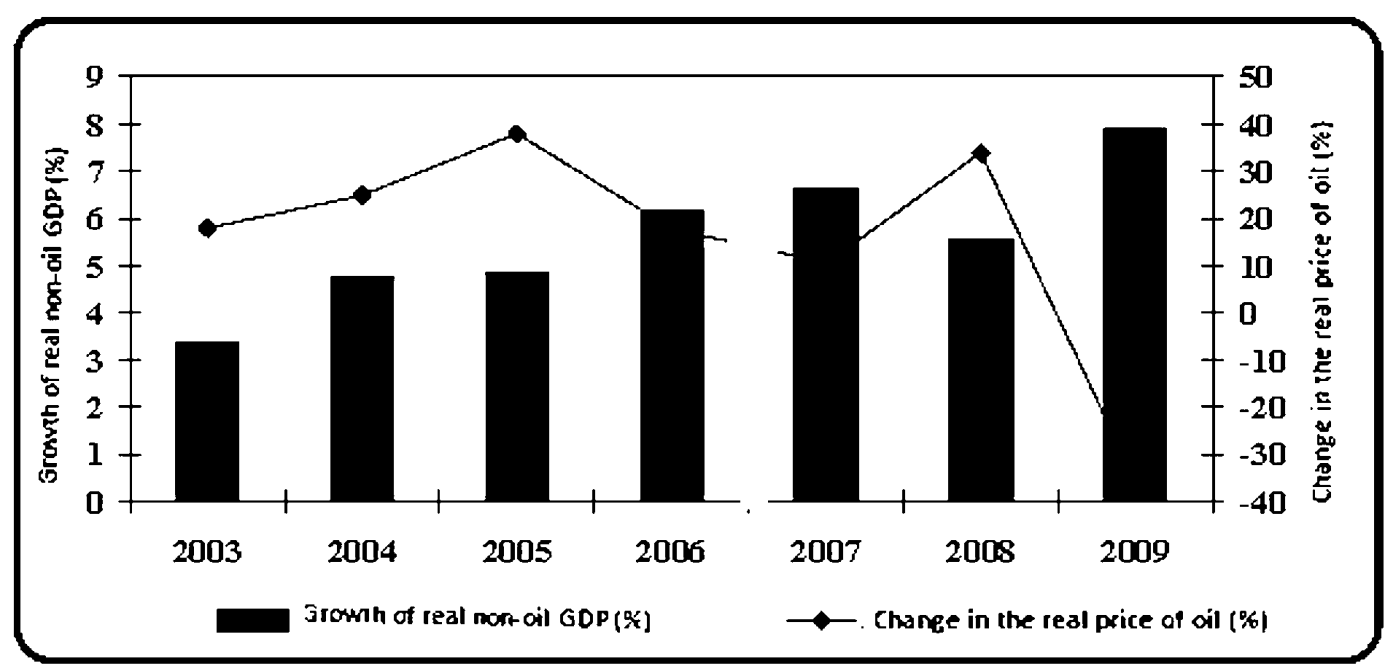

Figure 4. Comparison of growth of real non-oil GDP for the second group and the change in the real price of oil Source: OPEC Annual Statistical Report International Monetary Fund - Article IV report and national sources 




Figure 5. The direction of stock market indices for the countries of the third group and the CAC 40 index Source: Arab Monetary Fund - a database of Arab stock markets

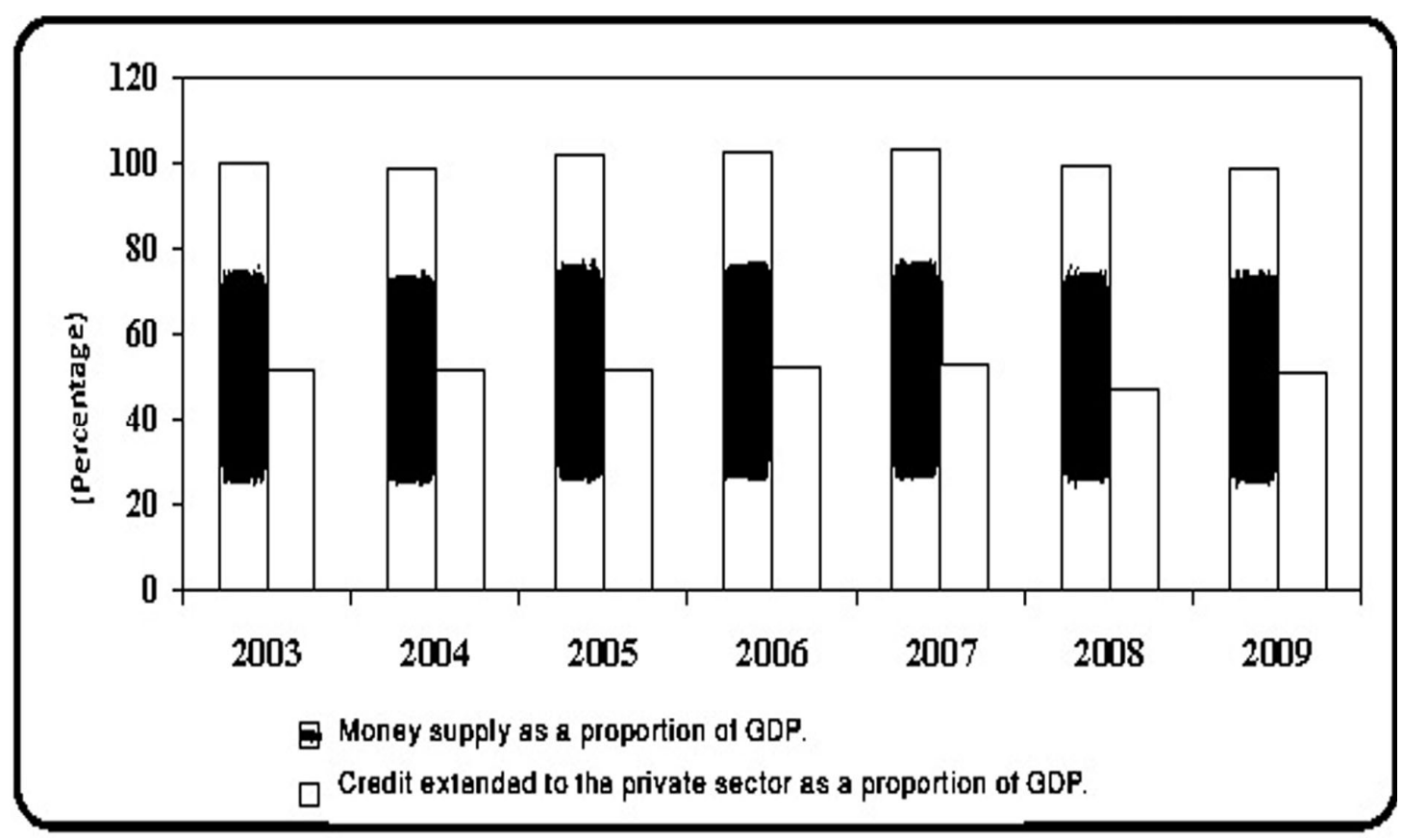

Figure 6. Money supply and credit extended to the private sector as a percentage of the gross GDP for the third group

Source: Survey unified Arab economic report for 2010 and previous years, the international monetary fund: International financial statistics (IFS) 


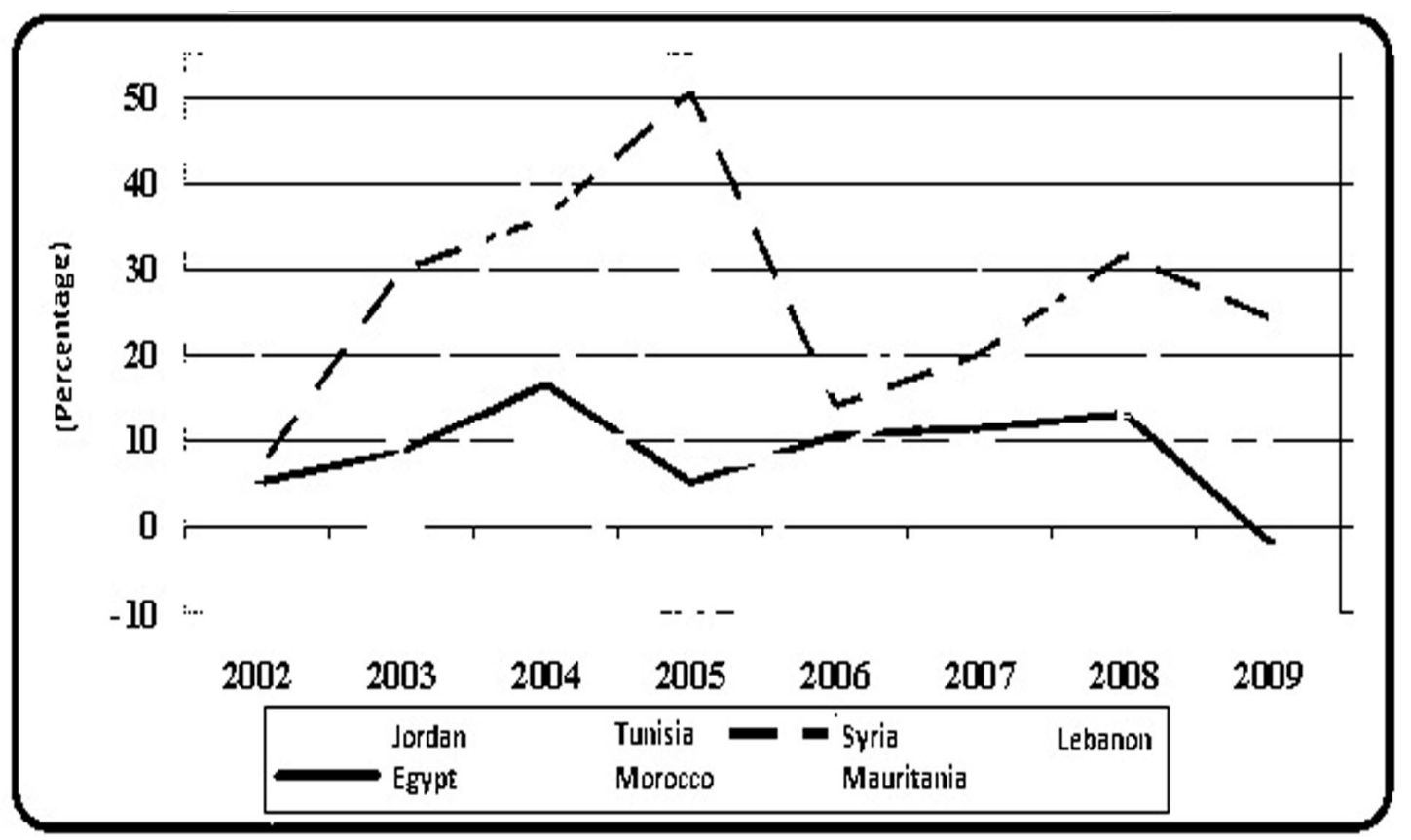

Figure 7. The direction of growth of bank loans to the private sector in the countries of the third group (percentage annual charge \%)

Source: National sources

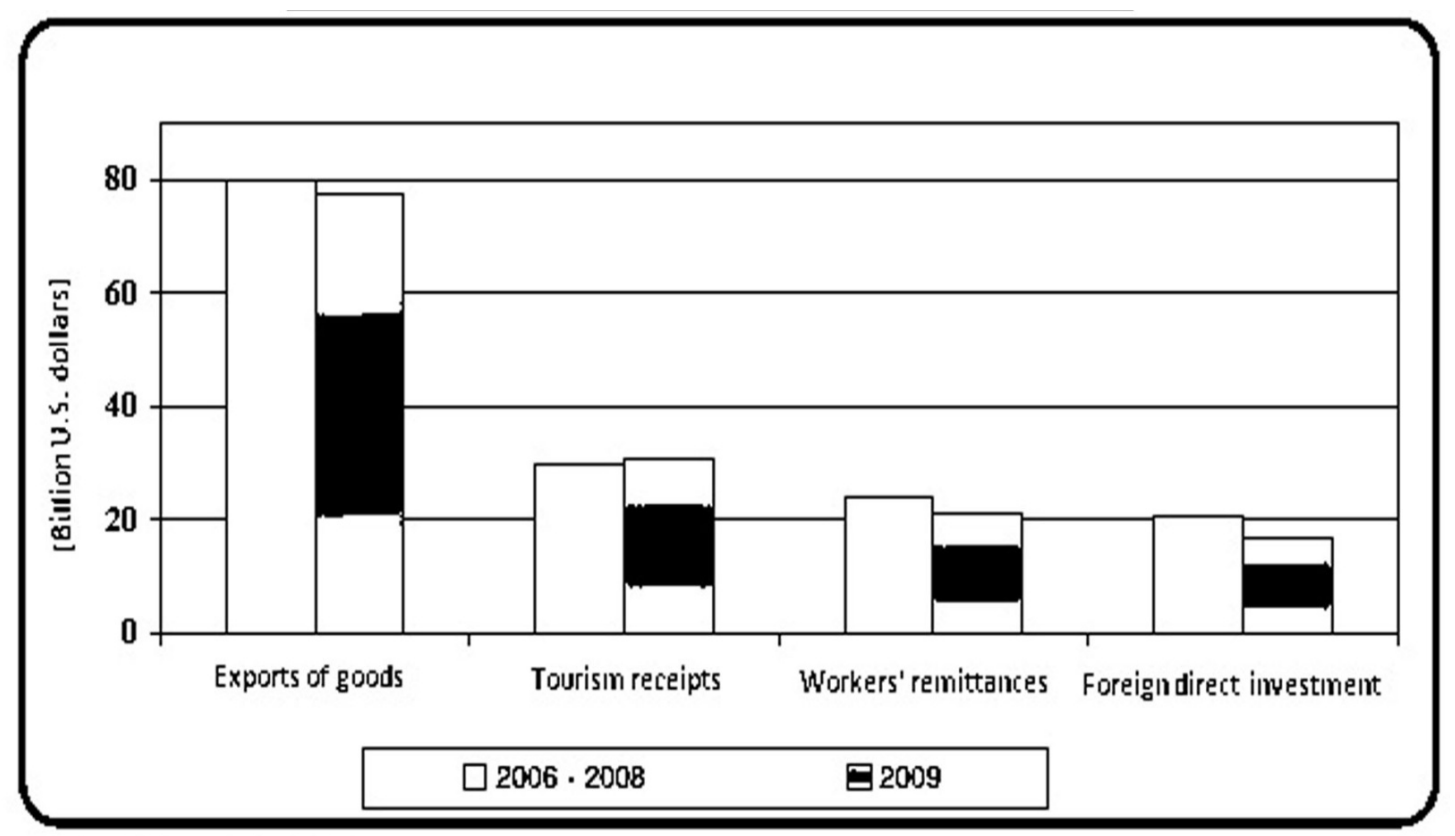

Figure 8. Some economic indicators for countries of the third group

Source: National sources 